\title{
Intratumoral hyperthermic chemotherapy injection in peripheral non-small cell lung cancer
}

\author{
Mohamed A. Tohlob, Lucy A. Suliman, Ahmed S. Elmorsy, Mohamed A. Ibrahim and Asem A. Hewidy*
}

\begin{abstract}
Background: Intratumoral chemotherapy (ITC) has been used by many groups; the combination of heat and cytotoxic drugs increases the ability to destroy the malignant cells. The aim of this study was to assess the efficacy and safety of percutaneous injection of hyperthermic chemotherapy in conjunction with systemic chemotherapy as a palliative management of peripheral inoperable non-small cell lung cancer (NSCLC) compared to conventional systemic chemotherapy.

Results: There was a statistically significant improvement in quality of life score in group A and B, but deterioration in group $C$ after 6 months. As regards radiology, after 6 months in group A, one patient (10\%) showed complete response, 6 patients (60\%) showed partial response, one patient (10\%) stable response, and two patients (20\%) showed progression; in group B, 6 patients (60\%) showed partial response, two patients (20\%) showed stable response, and two patients (20\%) showed progression; and in group C, 7 patients (70\%) showed progression, two patients (20\%) showed partial response, and one patient (10\%) showed stable response. There were few controllable complications. Median survival in group A was 16 months, in group B was 15 months, and in group C was 8 months.
\end{abstract}

Conclusion: Intratumoral hyperthermic chemotherapy is a promising, effective, harmless palliative therapy for inoperable peripheral NSCLC.

Keywords: Lung cancer, Locoregional, Hyperthermic chemotherapy

\section{Background}

Bronchogenic carcinoma is the main cause of cancer deaths in which only $16 \%$ of patients are diagnosed at earlier stage [1]. Most of patients at the time of diagnosis are inoperable. Several studies postulated that debulking of malignant mass has a significant role in improving survival and enhancing quality of life. There are several methods which have been used for palliative management of locally advanced peripheral lung cancer [2].

Systemic administration of chemotherapy protocols can lead to several adverse effects which can lead to

\footnotetext{
* Correspondence: ahewidy@yahoo.com

Faculty of Medicine, Chest Department, Mansoura University, Algomhoria street, Mansoura City, Egypt
}

stoppage of chemotherapy regimen with serious impacts on health economics [3].

Locoregional administration of chemotherapeutic drugs has been encouraged by many research groups as emerging theoretical approach in the form of intratumoral chemotherapy (ITC) [4]. Hyperthermia in the range of 40 to $45^{\circ} \mathrm{C}$ has a cytotoxic potential, and cells are directly killed by this modality, also it modifies the radiosensitivity or chemosensitivity of cells and tissues. Thus, the effect of other modalities is enhanced by sensitization through hyperthermia [5].

Hyperthermic intraperitoneal chemotherapy (HIPEC) in patients with abdominal cancers had significant survival advantage compared to standard of care. Cisplatin

\section{SpringerOpen}

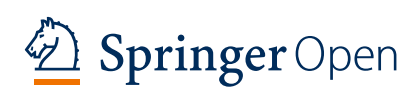

(c) The Author(s). 2020 Open Access This article is licensed under a Creative Commons Attribution 4.0 International License, which permits use, sharing, adaptation, distribution and reproduction in any medium or format, as long as you give appropriate credit to the original author(s) and the source, provide a link to the Creative Commons licence, and indicate if changes were made. The images or other third party material in this article are included in the article's Creative Commons licence, unless indicated otherwise in a credit line to the material. If material is not included in the article's Creative Commons licence and your intended use is not permitted by statutory regulation or exceeds the permitted use, you will need to obtain permission directly from the copyright holder. To view a copy of this licence, visit http://creativecommons.org/licenses/by/4.0/. 
is the mostly used agent for HIPEC as it has a direct cytotoxic activity [6].

We need a palliative modality for peripheral non-small cell lung cancer (NSCLC) that can reduce the side effect of systemic chemotherapy and acts as a debulking method for the tumor mass. The aim of our study was to evaluate the efficacy and safety of percutaneous injection of hyperthermic chemotherapy plus systemic chemotherapy as a palliative therapy of peripheral inoperable NSCLC compared to systemic chemotherapy.

\section{Methods}

The study was done at the Chest Department and Oncology Center, Mansoura University, Egypt, from January 2017 to February 2019. Ethical agreement had been obtained from the Institutional Research Board, Faculty of Medicine, Mansoura University. Our study had been registered in the Pan African Clinical Trial Registry under the code PACTR201702001974160. Patients signed informed consents after description of the study protocol.

The included patients were subjected to random selection by closed envelope method and divided into 3 groups:

- Group A. Patients were treated with percutaneous transthoracic intratumoral injection of hyperthermic cisplatin (Cisplatin, Mylan) at $40-45^{\circ} \mathrm{C}$ plus systemic chemotherapy. Seven patients were inoperable and 3 patients were unfit due to poor cardiopulmonary reserve.

- Group B. Patients were treated with percutaneous transthoracic intratumoral injection of cisplatin at room temperature $20-25^{\circ} \mathrm{C}$ plus systemic chemotherapy as positive control group. Six patients were inoperable, 3 patients were unfit due to poor cardiopulmonary reserve, and one patient refused surgery.

- Group C. Patients were treated with systemic conventional chemotherapeutic protocol as negative control group. Six patients were inoperable and 4 patients were unfit due to poor cardiopulmonary reserve.

\section{Inclusion criteria}

Included patients fulfilled the following criteria: age more than 18 years, histologically diagnosed peripherally located NSCLC, who were not candidates for surgery because of poor cardiopulmonary status, inoperable advanced stage of lung cancer or refusal of surgery, and were candidate for chemotherapy with good bone marrow reserve (white blood cell count $>3500 / \mathrm{mm}^{3}$, neutrophil count $>1800 / \mathrm{mm}^{3}$, hemoglobin $>10 \mathrm{~g} / \mathrm{dL}$, and hematocrit value $>30 \%$ [7]).

\section{Exclusion criteria}

Patients with any of the following criteria were operable or with uncorrectable bleeding diathesis, uncompensated cardiac comorbidities, had malignancies other than NSCLC (small cell lung cancer, metastasis, lymphoma, sarcoma, others) or hypersensitive to cisplatin were excluded.

All included patients were subjected to the following:

1. Clinical evaluation

(a) Thorough medical history followed by full clinical examination. Quality of life score was assessed [8].

2. Laboratory work up

(a) Complete blood picture, liver function, renal function, coagulation tests, and arterial blood gasses analysis

3. Radiological work up

(a) X-ray chest was done at presentation and in every session post-injection to detect any complication

(b) Computed tomography of the chest was done in the following sequence:

I Diagnosis with CT-guided tru-cut biopsy and to evaluate the size by $\mathrm{CT}$ volumetry, local extent of the tumor, and regional lymph nodes, for treatment planning and dose optimization; CT was done again after 3 months and 6 months of treatment.

II Radiological response was evaluated by modified response evaluation criteria in solid tumors (RECIST) for objective evaluation of treatment responses [9].

(c) CT abdomen, CT brain and bone scan to exclude of distant metastasis.

4. Fiberoptic bronchoscopy

(a) It was done for all patients at presentation for endobronchial lesion and staging, using bronchoscope (Pentax FB 19 TV) manufactured by Pentax, Tokyo, Japan.

5. Staging

(a) Staging was done by the seventh TNM staging for NSCLC [10] till publication of the 8th edition; patients were staged according to 8th edition [11].

6. Technique

(a) Ondansetron $8 \mathrm{mg}$ was administered intravenously $30 \mathrm{~min}$ before injection as a central antiemetic.

(b) After disinfection of the skin with povidone iodine, anesthesia was reached with local injection of $2 \%$ lidocaine hydrochloride $(15-20 \mathrm{ml})$ into the skin and deeper tissues. 
(c) CT or ultrasound was used to localize the tumor and determine the ideal approach. We selected the entry site least probable to injure vessels or nerves and allowing a least depth of the needle inside the lesion to decrease displacement from patients' breathing or movement.

(d) Oxygen saturation and ECG was observed during and 1 day after the technique.

(e) Hyperthermic or normothermic chemotherapy (cisplatin) was injected (by conventional 50-ml syringe surrounded by insulating cover) slowly utilizing a 22-gauge needle by varying the distance and rotating the needle, hoping the agent was widely distributed within the tumor.

(f) Calculation of the intratumoral chemotherapy drug volume was performed using the formula by Monga et al. [12] and computed tomography CT scans (in $\mathrm{mL}$ ITC-drug):

Volume $=0.5 \times$ maximum height $\times$ maximum width $\times$ maximum depth.Injection of ITC and systemic chemotherapy was done according to the following protocol:

\begin{tabular}{llllllll}
\hline Start & 7 day & 14 day & 21 day & 28 day & 35 day & 42 day & 49 day \\
\hline IV & ITC & ITC & ITC & IV & ITC & ITC & ITC \\
\hline
\end{tabular}

(g) In each cycle, $70 \%$ of systemic dose was injected intravenously and the rest of total dose was divided into 3 doses each was injected percutaneous transthoracic into the tumor [13].

(h) Chest X-ray was done immediately after hyperthermic or normothermic chemotherapy injection to distinguish the early complications. (i) Second and third CT chest were done after 3 and 6 months to assess the changes in the enhancement pattern (solid mass, necrosis, or cavitation), lesion size, lymph node, and late complications.

7. Chemotherapy protocol

(a) The chemotherapy was given during the ablation treatment; all patients were treated with cisplatin $75 \mathrm{mg} / \mathrm{m}^{2}$ on day 1 plus gemcitabine $1250 \mathrm{mg} / \mathrm{m}^{2}$ on days 1 and 8 every 3 weeks. Seventy percent of systemic dose of cisplatin was given on day 1 by intravenous infusion over $120 \mathrm{~min}$. Gemcitabine was given on days 1 and 8 by intravenous infusion over 30 min [14]. Smaller dose of intravenous administered chemotherapy as 70\% administered intravenously and 30\% injected intratumorally in groups of locoregional therapy.

8. Follow up

(a) Complications: Rule out any possible complications for the first $24 \mathrm{~h}$ post each session

(b) Efficacy:

I Quality of life score

II Radiological evaluation was done by CT chest after 3 and 6 months

\section{Statistical analysis}

Data was analyzed by SPSS (Statistical Package for Social Sciences) version 25 (International Business Machines Corporation, New York, USA). The demographic, clinical, radiological, and pathological data gathered together with the patients' outcome were tabulated and statistically analyzed. Qualitative data were presented as

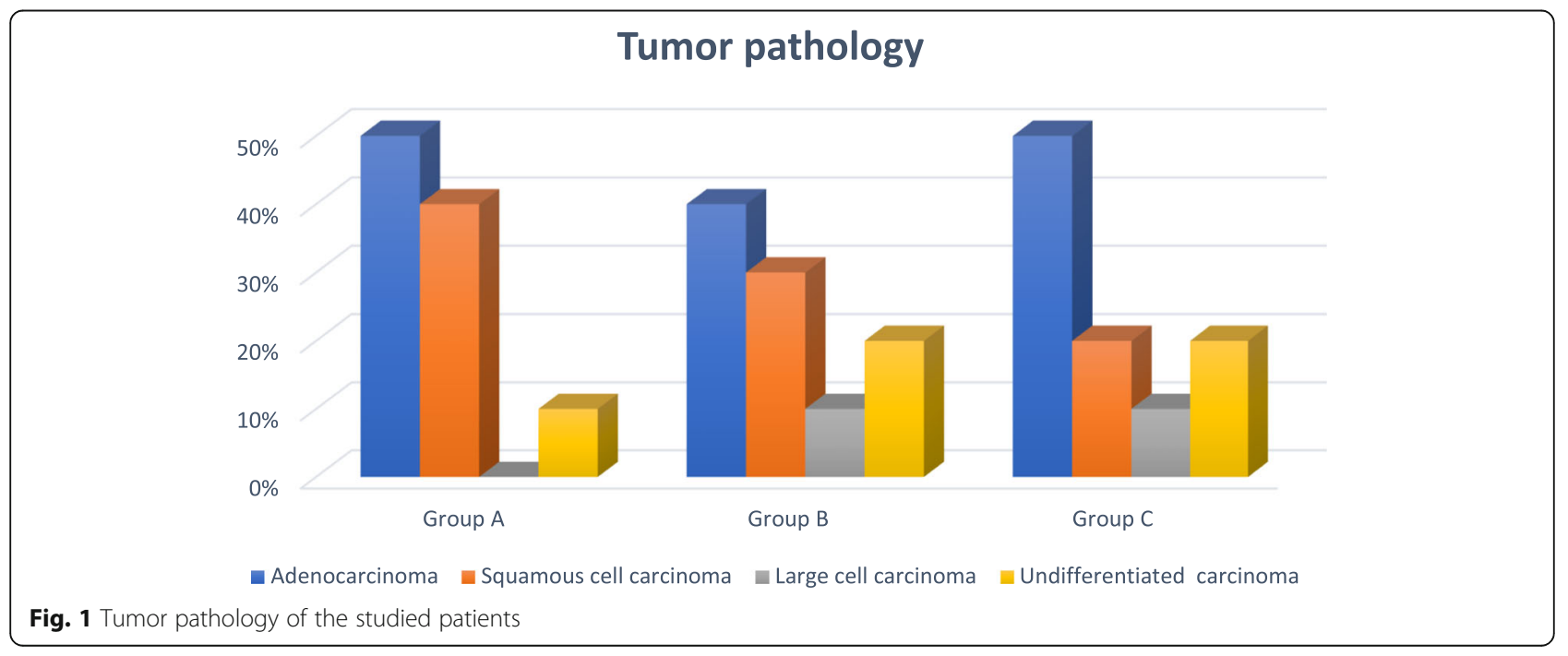


Table 1 Quality of life score before therapy and 3 and 6 months after therap y[8]

\begin{tabular}{|c|c|c|c|c|c|c|}
\hline & Group A $(\boldsymbol{n}=10)$ & Group B $(\boldsymbol{n}=10)$ & Group C $(\boldsymbol{n}=10)$ & P1 & $\mathrm{P} 2$ & P3 \\
\hline & Median (min-max) & Median (min-max) & Median (min-max) & & & \\
\hline Quality of life (before) & $1(0-1)$ & $1(0-1)$ & $1(0-2)$ & 0.342 & 0.168 & 0.070 \\
\hline At $3 \mathrm{~m}$ & $0(0-1)$ & $1(0-1)$ & $3(1-3)$ & 0.189 & 0.000 & 0.000 \\
\hline At $6 \mathrm{~m}$ & $0(0-2)$ & $1(0-3)$ & $3(1-4)$ & 0.277 & 0.001 & 0.003 \\
\hline Pre vs. $3 \mathrm{~m}$ & 0.025 & 1.000 & 0.006 & & & \\
\hline Pre vs. $6 \mathrm{~m}$ & 0.257 & 0.317 & 0.006 & & & \\
\hline
\end{tabular}

$P 1, P$ between group $A$ and $B ; P 2, P$ between group $A$ and $C ; P 3, P$ between group $B$ and $C$

number and percent and Chi square test was applied to compare between 3 groups. Paired sample $t$ test was applied to compare the data before and after treatment in each group. ANOVA, repeated measure ANOVA, and post hoc analysis were used to detect significance between groups concerning parametric data. KruskalWallis, Wilcoxon, and Mann-Whitney were used to detect significance between groups concerning nonparametric data. Kaplan-Meier test was achieved to measure survival and detect significance between groups.

\section{Results}

Group A included 10 patients (51.20 \pm 9.69 years old), group B included 10 patients (56.80 \pm 8.36 years old), and group $C$ included 10 patients $(57.90 \pm 8.05$ years old). The three groups were matched regarding the age, gender, and smoking status.

No statistically significant differences between three groups regarding tumor pathology as shown in Fig. 1.

There was significant reduction in quality of life score in group A after 3 months. There was significant rise in quality of life score in group $\mathrm{C}$ after 3 and 6 months of therapy. There was significant rise in quality of life score in group C versus group A and group B after 3 and 6 months of therapy as shown in Table 1.
There was significant improvement in radiological response between group $\mathrm{A}$ and $\mathrm{C}$ after 3 and 6 months of intratumoral therapy. There was statistically significant improvement in radiological response between group B and group $\mathrm{C}$ after 3 and 6 months of intratumoral therapy as shown in Table 2. One case was shown in Fig. 2.

As regards early complications of intratumoral chemotherapy in the current study, chest pain was noted in all patients in group A and B and was controlled by analgesics. Hemoptysis was recorded in 1 patient (10\%) in group A and 2 patients (20\%) in group B and controlled by hemostatic. Four patients (40\%) of group A and 3 patients $(30 \%)$ in group B had fever. Pneumothorax was recorded in 2 patients $(20 \%)$ in group B and improved spontaneously with oxygen therapy. There was no procedure related mortality.

As shown in Fig. 3, there were no statistically significant differences between the three groups as regards tumor volume after 3 and 6 months of start of treatment $(P>0.05)$. After 3 and 6 months of beginning locoregional therapy, there was statistically significant reduction of tumor volume in group A and group B but not in group $\mathrm{C}$,

The complications of chemotherapy in the present study were shown in Table 3 which were less in group A and $\mathrm{B}$ than in group $\mathrm{C}$.

Table 2 Radiological response after 3 and 6 months of therapy measured with CT chest (modified RECIST criteria)

\begin{tabular}{|c|c|c|c|c|c|c|c|}
\hline & \multicolumn{2}{|c|}{ Group A $(\boldsymbol{n}=10)$} & \multicolumn{2}{|c|}{ Group B $(\boldsymbol{n}=10)$} & \multicolumn{2}{|c|}{ Group C $(\boldsymbol{n}=10)$} & \multirow[t]{2}{*}{$\boldsymbol{P}$ value } \\
\hline & No & $\%$ & No & $\%$ & No & $\%$ & \\
\hline Post 3 months & & & & & & & $\mathrm{P} 1=0.654, \mathrm{P} 2=0.006, \mathrm{P} 3=0.010$ \\
\hline Complete response & 0 & $0 \%$ & 0 & $0 \%$ & 0 & $0 \%$ & \\
\hline Partial response & 8 & $80 \%$ & 7 & $70 \%$ & 2 & $20 \%$ & \\
\hline Stable & 1 & $10 \%$ & 2 & $20 \%$ & 1 & $10 \%$ & \\
\hline Progression & 1 & $10 \%$ & 1 & $10 \%$ & 7 & $70 \%$ & \\
\hline Post 6 months & & & & & & & $P 1=0.548, P 2=0.019, P 3=0.032$ \\
\hline Complete response & 1 & $10 \%$ & 0 & $0 \%$ & 0 & $0 \%$ & \\
\hline Partial response & 6 & $60 \%$ & 6 & $60 \%$ & 2 & $20 \%$ & \\
\hline Stable & 1 & $10 \%$ & 2 & $20 \%$ & 1 & $10 \%$ & \\
\hline Progression & 2 & $20 \%$ & 2 & $20 \%$ & 7 & $70 \%$ & \\
\hline
\end{tabular}

$P 1, P$ between group $A$ and $B ; P 2, P$ between group $A$ and $C ; P 3, P$ between group $B$ and $C$ 

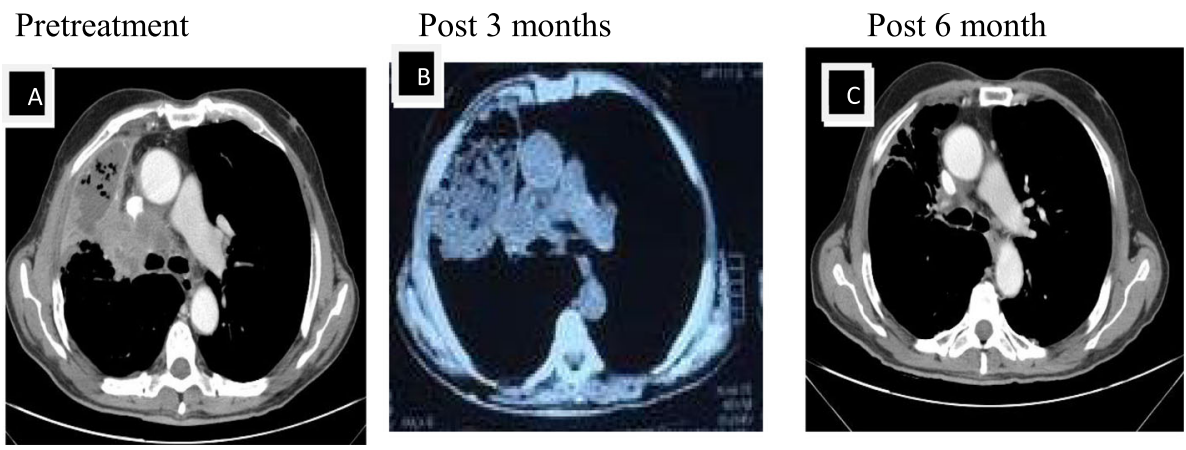

Fig. 2 Male patient 44 years, non-smoker, diagnosed as adenocarcinoma. CT showed right upper lobe mass (a before treatment, $\mathbf{b}$ post 3 months showed partial response, and c post 6 months showed complete response), and treated by intratumoral hyperthermic cisplatin plus systemic chemotherapy

No significant difference in survival between group A and B (Fig. 4). There was statistically significant increase in survival between group $A$ and $B$ and group $C$ as shown in Table 4.

\section{Discussion}

The locoregional administration of chemotherapy has been used by many studies as ITC, brachytherapy, photodynamic therapy, and aerosol chemotherapy. These studies assessed the safety and efficacy of locoregional therapies and the reduction of side effects of systemic chemotherapy [13].

In clinical studies, cisplatin was used for ITC because cisplatin is one of the most effective agents against NSCLC. ITC with cisplatin has been successfully utilized in the therapy of different types of localized malignant tumors [15].

The combination of heat and cytotoxic drugs dramatically increased capacity of destroying cancer cells by augmented membrane permeability, enhanced membrane transport, altered cellular metabolism, changed drug pharmacokinetics and excretion, and augmented drug penetration [16].

To the best of our knowledge, this is the initial work assessing effectiveness and safety of local administration of hyperthermic chemotherapy in peripheral inoperable NSCLC. We support our results with those of other locoregional therapy; intratumoral chemotherapy, radiofrequency, and microwave ablation of peripheral lung cancer.

Regarding quality of life score (increase in score means worsening of quality of life) as shown in Table 1, our results were more than El-Badrawy et al. [17], in which there were no statistically significant changes in the score in group treated by intratumoral hot saline injection plus systemic chemotherapy versus before treatment, while a significant rise in the score in the group treated by intratumoral saline at room temperature plus systemic chemotherapy after 3 months of treatment. Our results were in agreement with $\mathrm{He}$

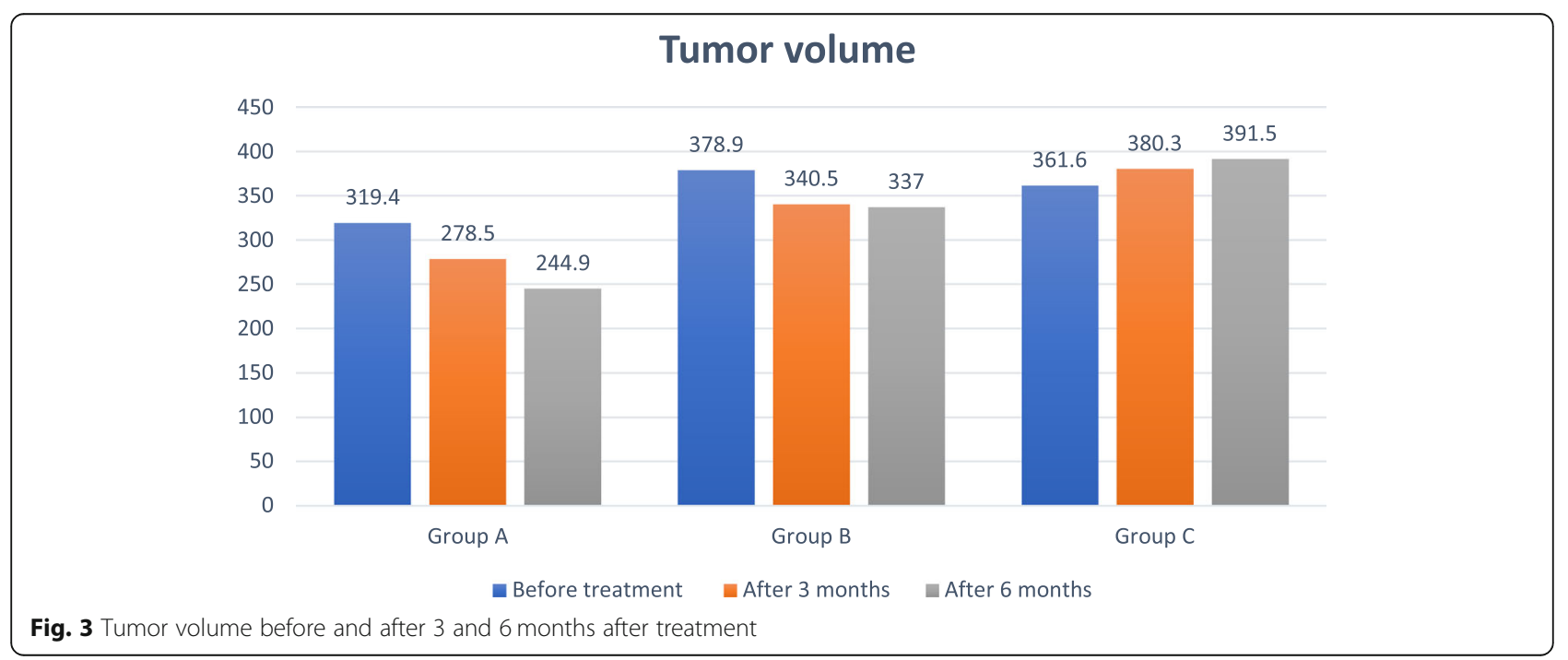


Table 3 Chemotherapy complications (CTCAE 2017)

\begin{tabular}{|c|c|c|c|c|c|c|}
\hline \multirow[t]{2}{*}{ Complications } & \multicolumn{2}{|c|}{ Group A $(\boldsymbol{n}=10)$} & \multicolumn{2}{|c|}{ Group B $(\boldsymbol{n}=10)$} & \multicolumn{2}{|c|}{ Group C $(\boldsymbol{n}=10)$} \\
\hline & $\bar{n}$ & $\%$ & $\bar{n}$ & $\%$ & $\bar{n}$ & $\%$ \\
\hline Nausea + vomiting & 6 & 60 & 5 & 50 & 7 & 70 \\
\hline Neutropenia $\left(\right.$ ANC $<1000 / \mathrm{mm}^{3}$ ) & 2 & 20 & 3 & 30 & 5 & 50 \\
\hline Anemia $(\mathrm{Hb}<10 \mathrm{~g} / \mathrm{dl})$ & 2 & 20 & 2 & 20 & 3 & 30 \\
\hline Thrombocytopenia(Plt $<150,000 / \mathrm{mm}^{3}$ ) & 2 & 20 & 1 & 10 & 2 & 20 \\
\hline Cardiomyopathy & 0 & 0 & 0 & 0 & 3 & 30 \\
\hline Renal impairment (increase creatinine $\geq 0.3 \mathrm{mg} / \mathrm{dl}$ ) & 1 & 10 & 2 & 20 & 7 & 70 \\
\hline
\end{tabular}

et al. [18] in which systemic gemcitabine plus cisplatin chemotherapy were used in conjunction with local paratoluenesulfonamide which was locally injected for peripherally advanced NSCLC larger than $3 \mathrm{~cm}$ who reported improvement in quality of life in $38 \%$ of patients.

The improvement in the life quality might be explained by decrease in tumor size and thermal effect on peripheral nerves. The differences between our results and these studies were due to dissimilar numbers of included patients, different modalities of locoregional therapy, variable stages, and pathology of lung cancer.

As regards the radiological response, as shown in Table 2, our results were equal to El-Badrawy et al. [17] who studied hot saline thermoablation of peripheral NSCLC. And by comparison to radiofrequency ablation, our results were near to $\mathrm{Li}$ et al. [19]. As compared to microwave ablation, these results were comparable to Sun et al. [20]. As compared to local chemotherapy ablation, these results were comparable to a study by $\mathrm{He}$ et al. [18] and our results were better than HohenforstSchmidt et al. [13].
As regards early complications of intratumoral chemotherapy in the current study as shown in Table 3, all these complications were controlled without intensive care unit admission. These results were comparable to El-Badrawy et al. [17]. Our study showed less complications than $\mathrm{Li}$ et al. [19]. The difference in tumor volume, smaller needle in our study could explain the differences in local complications.

The complications of chemotherapy in the present study as shown in Table 4, we found that chemotherapy complications in groups of locoregional therapy were less than group of chemotherapy alone and this was attributed to smaller dose of systemic chemotherapy used in groups of locoregional therapy. These results were equivalent to Gaafar et al. [21], who conducted a study of gemcitabin and cisplatin in 60 patients of inoperable NSCLC and reported neutropenia in $28.9 \%$ of patients, thrombocytopenia in $20 \%$ of patients, anemia in $18.6 \%$, nausea and vomiting in $28.8 \%$ of patients. In Hohenforst-Schmidt et al.'s [13] study, there were no severe adverse effects.

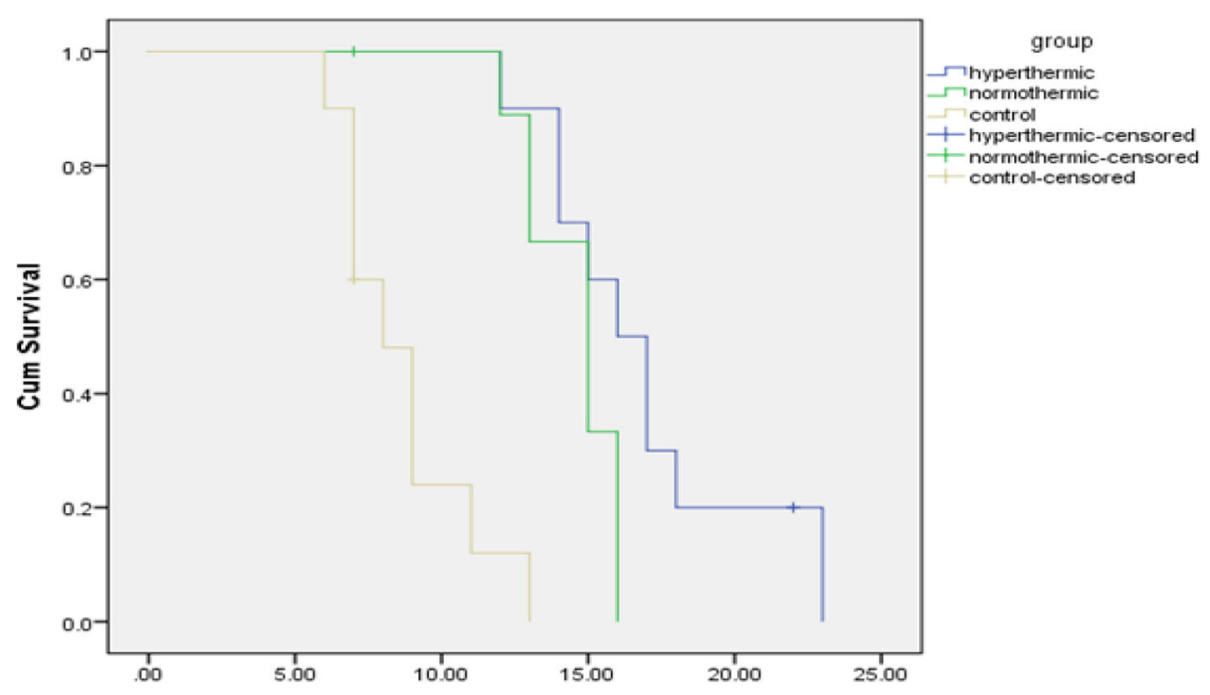

Fig. 4 Survival between groups at the end of our study 
Table 4 Overall survival at end of our study

\begin{tabular}{lllll}
\hline Survival in months & Group A $(\boldsymbol{n}=10)$ & Group B $(\boldsymbol{n}=10)$ & Group C $(\boldsymbol{n}=10)$ & $\boldsymbol{P}$ value \\
\hline Median in months & 16 & 15 & 8 & P1 $=0.056$, P2 $<0.001$, P3 $<0.001$ \\
$95 \% \mathrm{Cl}$ & $13.93-18.07$ & $13.15-16.85$ & $6.22-9.79$ &
\end{tabular}

$P 1, P$ between group $A$ and $B ; P 2, P$ between group $A$ and $C ; P 3, P$ between group $B$ and $C$

\section{Survival at the end of our study}

Our results were comparable to El-Badrawy et al. [17] in which 10 patients $(90.9 \%)$ were still alive and one patient (9.1\%) died, due to disease progression at the end of the study. These results were better than Ambrogi et al. [22] in which, 23 patients (40\%) were still alive at end of the study, but less than the results of Li et al. [19].

Many factors affect survival rate such as tumor size; Kodama et al. [23] published that size was a prognostic factor with 1- and 3-year overall survival rates of $100 \%$ and $79.8 \%$, respectively, in patients with tumors measuring less than $3 \mathrm{~cm}$, compared to $83.3 \%$ and $31.3 \%$ for tumors larger than $3 \mathrm{~cm}$. Also disease types, patients' overall condition, and comorbidities are very predictive of survival.

Limitations of our study were small number of cases, different pathological subtypes, and relatively large size of the tumors may have affected the results.

\section{Conclusion}

Intratumoral hyperthermic chemotherapy and intratumoral chemotherapy at room temperature are promising and inexpensive palliative treatments for patients with inoperable peripheral NSCLC. Regarding safety, intratumoral chemotherapy has few immediate side effects, but controllable with symptomatic treatment. Intratumoral hyperthermic chemotherapy and intratumoral chemotherapy at room temperature may improve quality of life.

\section{Abbreviations}

ITC: Intratumoral chemotherapy; NSCLC: Non-small cell lung cancer; HIPE C: Hyperthermic intraperitoneal chemotherapy; RECIST: Response evaluation criteria in solid tumors

\section{Acknowledgements}

No

\section{Authors' contributions}

All authors have read and approved the manuscript

MT had made substantial contributions to the conception, had approved the submitted version, and had agreed both to be personally accountable for the author's own contributions. LS had done design of the work, had approved the submitted version, and had agreed both to be personally accountable for the author's own contributions. AE had the acquisition, analysis and interpretation of data; had approved the submitted version; and had agreed both to be personally accountable for the author's own contributions. ME and $\mathrm{AH}$ had done the creation of new software used in the work and had approved the submitted version and had agreed both to be personally accountable for the author's own contributions.

\section{Funding}

The authors declare that they have no funding.
Availability of data and materials

The datasets used and/or analyzed during the current study are available from the corresponding author on reasonable request.

\section{Ethics approval and consent to participate}

Declared in the "Methods" section: Ethical approval had been obtained from the Institutional Research Board, Faculty of Medicine, Mansoura University. Our study had been registered in the Pan African Clinical Trial Registry under the code PACTR201702001974160. Patients signed their informed consents after explanation of study protocol.

Consent for publication

Not applicable

\section{Competing interests}

The authors declare that they have no competing interests.

Received: 1 May 2020 Accepted: 15 July 2020

Published online: 29 July 2020

\section{References}

1. Siegel R, Miller K, Jemal A (2017) Cancer statistics. CA Cancer J Clin 67:7-30

2. Dupuy D, DiPetrillo T, Gandhi S, Ready N, Ng T, Donat W, Mayo-Smith W (2006) Radiofrequency ablation followed by conventional radiotherapy for medically inoperable stage I non-small cell lung cancer. Chest 129:738-745

3. Mylonaki E, Manika K, Zarogoulidis P, Domvri K, Voutsas V, Zarogoulidis K, Mourelatos D (2012) In vivo synergistic cytogenetic effects of aminophylline on lymphocyte cultures from patients with lung cancer undergoing chemotherapy. Mut Res Fundamental Mol Mechanisms Mutagen 740:1-5

4. Kar U, Srivastava M, Andersson A, Baratelli F, Huang M, Rome LH, Sharma S (2011) Novel CCL21-vault nanocapsule intratumoral delivery inhibits lung cancer growth. PLoS One 6:e18758

5. Li G, Mivechi N, Weitzel G (1995) Heat shock proteins, thermotolerance, and their relevance to clinical hyperthermia. Int J Hyperth 11:459-488

6. Isık A, Sanlı M, Yılmaz M, Meteroglu F, Dikensoy O, Sevinc A, Camcı C, Tuncozgur B, Elbeyli L (2013) Intrapleural hyperthermic perfusion chemotherapy in subjects with metastatic pleural malignancies. Respir Med 107:762-767

7. Rossi S, Dore R, Cascina A, Vespro V, Garbagnati F, Rosa L, Ravetta V, Azzaretti A, Di Tolla P, Orlandoni G, Pozzi E (2006) Percutaneous computed tomographyguided radiofrequency thermal ablation of small unresectable lung tumours. Eur Respir J 27:556-563

8. Gridelli C, Ardizzoni A, Chevalier T, Manegold C, Perrone F, Thatcher N, Zandwijk N, Di-Maio M, Martelli O, De-Marinis F (2004) Treatment of advanced non small-cell lung cancer patients with ECOG performance status 2: results of a European Experts Panel. Ann Oncol 15:419-426

9. Fernando HC, De Hoyos A, Landreneau RJ, Gilbert S, Gooding WE, Buenaventura PO, Christie NA, Belani C, Luketich JD (2005) Radiofrequency ablation for the treatment of non-small cell lung cancer in marginal surgical candidates. J Thorac Cardiovasc Surg 129:639-644

10. Goldstraw P, Crowley J, Chansky K, Giroux D, Groome P, Rami-Porta R, Postmus P, Rusch V, Sobin L (2007) The IASLC Lung Cancer Staging Project: proposals for the revision of the TNM stage groupings in the forthcoming $7^{\text {th }}$ edition of the TNM Classification of malignant tumors. J Thorac Oncol 2:706-714

11. Goldstraw P, Chansky K, Crowley J, Rami-Porta R, Asamura H, Eberhardt W, Nicholson A, Groome P, Mitchell A, Bolejack V, International Association for the Study of Lung Cancer Staging and Prognostic Factors Committee, Advisory Boards, and Participating Institutions, International Association for the Study of Lung Cancer Staging and Prognostic Factors Committee Advisory Boards and Participating Institutions (2016) The IASLC Lung Cancer Staging Project: proposals for revision of the TNM stage groupings in the forthcoming (eighth) edition of the TNM Classification for Lung Cancer. J Thorac Oncol 11:39-51 
12. Monga S, Wadleigh R, Sharma A, Adib H, Strader D, Singh G, Harmon J, Berlin M, Monga D, Mishra L (2000) Intratumoral therapy of cisplatin/ epinephrine injectable gel for palliation in patients with obstructive esophageal cancer. Am J Clin Oncol 23:386-392

13. Hohenforst-Schmidt W, Zarogoulidis P, Darwiche K, Vog T, Goldberg EP, Huang H, Simoff M, Li Q, Browning R, Turner FJ, Pivert PL, Spyratos D, Zarogoulidis K, Celikoglu SI, Celikoglu F, Brachmann J (2013) Intratumoral chemotherapy for lung cancer: re-challenge current targeted therapies. Drug Design Dev Ther 7:571-583

14. Scagliotti G, Parikh P, von Pawel J, Biesma B, Vansteenkiste J, Manegold C, Serwatowski P, Gatzemeier U, Digumarti R, Zukin M, Lee JS, Mellemgaard A, Park K, Patil S, Rolski J, Goksel T, de Marinis F, Simms L, Sugarman KP, Gandara D (2008) Phase III study comparing cisplatin plus gemcitabine with cisplatin plus pemetrexed in chemotherapy-naive patients with advancedstage non-small-cell lung cancer. J Clin Oncol 26:3543-3551

15. Celikoglu F, Celikoglu S, York A, Goldberg E (2006) Intratumoral administration of cisplatin through a bronchoscope followed by irradiation for treatment of inoperable non-small cell obstructive lung cancer. Lung Cancer 51:225-236

16. Zhao Z, Zhao S, Ren M, Liu Z, Li Z, Yang L (2017) Effect of hyperthermic intrathoracic chemotherapy on the malignant pleural mesothelioma: a systematic review and meta-analysis. Oncotarget 8:100640-100647

17. El-Badrawy M, El-Shafey M, Hewidy A, Tohlob M, AkI F, Ebrahim M (2017) Hot saline thermoablation of peripheral non small cell lung cancer safety and efficacy: a pilot study. Int J Resp Dis Care Med 2:14-21

18. He J, Ying W, Yang H, Xu X, Shao W, Guan Y, Jiang M, Wu Y, Zhong B, Wang D, Tucker S, Zhong N (2009) Gemcitabine plus cisplatin chemotherapy with concurrent para-toluenesulfonamide local injection therapy for peripherally advanced nonsmall cell lung cancer larger than 3 $\mathrm{cm}$ in the greatest dimension. Anti-Cancer Drugs 20:838-844

19. Li X, Zhao M, Wang J, Fan W, Li W, Pan T, Wu P (2013) Percutaneous CTguided radiofrequency ablation as supplemental therapy after systemic chemotherapy for selected advanced non-small cell lung cancers. AJR 201: 1362-1367

20. Sun Y, Song P, Guo Y, Sheng L (2015) Computed tomography-guided percutaneous microwave ablation therapy for lung cancer. Genet Mol Res 14:4858-4864

21. Gaafar R, Hamza R, Khaled H, El-Serafi M, Mansour O, Karim N, Abdelmoneim D, El-Attar I, Soliman S (2004) Gemcitabine and cisplatin in the treatment of advanced non - small cell lung cancer: National Cancer Institute Cairo experience. J Egyptian Nat Cancer Inst 16:1-7

22. Ambrogi M, Fanucchi O, Cioni R, Dini P, De Liperi A, Cappelli C, Davini F, Bartolozzi C, Mussi A (2011) Long-term results of radiofrequency ablation treatment of stage I non-small cell lung cancer: a prospective intention-totreat study. J Thorac Oncol 6:2044-2051

23. Kodama H, Yamakado K, Takaki H, Kashima M, Uraki J, Nakat-suka A, Takao M, Taguchi O, Yamada T, Takeda K (2012) Lung radiofrequency ablation for the treatment of unresectable recurrent non-small-cell lung cancer after surgical intervention. Cardiovasc Intervent Radiol 35:563-569

\section{Publisher's Note}

Springer Nature remains neutral with regard to jurisdictional claims in published maps and institutional affiliations.

\section{Submit your manuscript to a SpringerOpen ${ }^{\circ}$ journal and benefit from:}

- Convenient online submission

- Rigorous peer review

- Open access: articles freely available online

- High visibility within the field

- Retaining the copyright to your article

Submit your next manuscript at $\boldsymbol{\nabla}$ springeropen.com 